\title{
Anti-Müllerian hormone and response to ovulation induction with clomiphene citrate in women with polycystic ovary syndrome
}

\author{
Mohamed S. Sweed ${ }^{1 *}$, Osama S. El-Kady ${ }^{1}$, Eman A. AbdElSalam ${ }^{2}$, Mohammed M. Mostafa $^{3}$
}

\author{
${ }^{1}$ Department of Obstetrics and Gynecology, Ain-Shams University, Cairo, Egypt \\ ${ }^{2}$ Department of Radiodiagnosis, Ain-Shams University, Cairo, Egypt \\ ${ }^{3}$ Department of Obstetrics and Gynecology, Cairo University, Cairo, Egypt
}

Received: 27 January 2016

Accepted: 10 February 2016

\section{*Correspondence:}

Dr. Mohamed S. Sweed,

E-mail: drmsweed@med.asu.edu.eg

Copyright: () the author(s), publisher and licensee Medip Academy. This is an open-access article distributed under the terms of the Creative Commons Attribution Non-Commercial License, which permits unrestricted non-commercial use, distribution, and reproduction in any medium, provided the original work is properly cited.

\begin{abstract}
Background: Anti-Müllerian hormone (AMH) is suggested as an important marker for women with polycystic ovary disease (PCOS). Several studies have found serum level of AMH correlate well to ovarian response to ovulation induction in women with PCOS. This study was conducted to assess the relationship between AMH in women with PCOS and response to ovulation induction with clomiphene citrate.

Methods: Prospective observational cohort study conducted at Ain-Shams university maternity hospital from February 2013 to February 2014. 100 women with PCOS were recruited from the infertility outpatient clinic. Serum AMH levels were measured by enzyme linked immunosorbent assay in the early follicular phase (days 3-5). Ovulation induction by clomiphene citrate was started on day 5 as $50 \mathrm{mg}$ daily tablet for 5 days. Ovulation was documented by transvaginal ultrasonography and women who failed to ovulate till day 35 were considered anovulatory.

Results: 72 women ovulated within 12 to 33 days of the menstrual cycle, while 28 had undetectable ovulation till day 35. The median serum AMH level was significantly higher in women with failed ovulation [4.05 ng/mL (3.7 - 4.4)] than in ovulating women $[2.7 \mathrm{ng} / \mathrm{mL}(1.9-3.1)](\mathrm{p}<0.001)$. Receiver-operating characteristic (ROC) curve analysis found the best cutoff value of $\mathrm{AMH}$ for prediction of successful ovulation $\leq 3.6 \mathrm{ng} / \mathrm{mL}$ (sensitivity $=97.2 \%$, specificity $=82.1 \%$ ).

Conclusions: Anti-Müllerian hormone is a very useful predictor of poor responders to clomiphene citrate among women with polycystic ovary disease.
\end{abstract}

Keywords: Anti-Müllerian hormone, Anovulation, Clomiphene citrate, Polycystic ovary disease, Poor responders

\section{INTRODUCTION}

Polycystic ovary syndrome (PCOS) is one of the commonest endocrinopathies affecting females and female infertility. ${ }^{1}$ It affects almost $5-10 \%$ of women during their reproductive age. ${ }^{2}$ It was first described by Stein and Leventhal in 1935 who found women with polycystic ovaries and amenorrhea where some complained of hirsutism and/or obesity. ${ }^{3}$ A significant number of PCOS patients are first presented by infertility as their main complaint, owing mainly to anovulation as the primary defect responsible for failure of conception. ${ }^{4}$

Clomiphene citrate (CC) seems to be an efficient, low cost treatment for anovulatory PCOS with minimal adverse effects. ${ }^{5}$ Normally, $60-85 \%$ will ovulate using CC as first-line treatment. ${ }^{6,7}$ Still, almost $15-20 \%$ of women remain anovulatory where $\mathrm{CC}$-resistance is usually diagnosed after 3-6 months of treatment. ${ }^{8,9}$ Earlier diagnosis of CC-resistance could spare the patients the 
psychological stress and allow them to shift to secondline treatment.

Anti-Müllerian hormone (AMH), one of the members of transforming growth factor-beta (TGF- $\beta$ ) superfamily is suggested as an important marker for women with PCOS being 2 to 3 folds higher than in healthy women. ${ }^{10}$ These elevated levels of AMH are directly related to the increased number of follicles in women with PCOS. ${ }^{11}$ Indeed, several studies have found serum level of AMH correlate well to ovarian response to ovulation induction in women with PCOS. ${ }^{12-14}$

This study was conducted to assess the relationship between $\mathrm{AMH}$ in women with PCOS and response to ovulation induction with $\mathrm{CC}$.

\section{METHODS}

This prospective observational cohort study was conducted at Ain-Shams University Maternity Hospital from February 2013 to February 2014. 100 women were recruited from the infertility outpatient clinic with PCOS diagnosed according to androgen excess society (AES) guidelines $2006 .{ }^{15}$ Women with extremes of reproductive age (less than 20 years old or more than 35 years old), other causes of infertility, thyroid dysfunction, diabetes, using hormonal drugs within the previous 2 months and women presented with ovarian pathology (e.g. cysts, tumors etc.) were excluded from the study. The study was approved by the ethical committee of the department of Obstetrics and Gynecology, Ain-Shams university and informed written consents were obtained from all participants before commencement of the study.

All patients were subjected to thorough history and examination, Body mass index (BMI) was calculated and body hair distribution was noted using modified Ferriman-Gallwey score where a score of 8 or higher was indicative of androgen excess. ${ }^{16}$ Serum FSH, LH, TSH, prolactin and free testosterone were obtained as part of the routine workup of patients with PCOS.

Serum AMH levels were measured by enzyme linked immunosorbent assay (AMH Gen II ELISA kit; Immunotech A Beckman coulter company, Brea, CA, U.S.A.). Blood samples were obtained during the early follicular phase (days 3-5) and in case of amenorrhoeic women, 2 tablets $(10 \mathrm{mg})$ oral medroxy-progesterone acetate (Provera ${ }^{\circledR}$, Pharmacia, Egypt) was given for 7 days to induce withdrawal bleeding. ${ }^{17} \mathrm{CC}$ (Clomid $\AA$, Aventis, Egypt) was started on day 5 as $50 \mathrm{mg}$ daily tablet for 5 days. Folliculometry was started on day 11 using trans-vaginal ultrasound (Medison, sonoscape A6 model, 6.5 MHz endovaginal probe) and continued till ovulation was confirmed by ultrasonography where the date of ovulation was documented. Women who failed to ovulate till day 35 were considered anovulatory.
The required sample size has been calculated using PASS $\odot$ version 11 (NCSS, LLC. Kaysville, Utah, USA). The primary outcome measure was the incidence of ovulation after attempted induction of ovulation with $\mathrm{CC}$ in patients with PCOS in relation to serum AMH level. It has been estimated that a sample size of 100 patients would achieve a power of $95 \%$ (type II error $=0.02$ ) to detect a difference of 0.2 in the area under the curve (AUC) for prediction of successful ovulation. The AUC was assumed to be 0.5 under the null hypothesis and to be 0.7 under the alternative hypothesis. An AUC of 0.7 was selected as it is regarded as denoting fair predictive value of the test hormone. ${ }^{18}$ The true positive rate (i.e., successful ovulation) has been assumed to be $50 \%$ and the true negative rate (i.e., failed ovulation) to be $50 \%$. These rates have been based on the figures reported by. ${ }^{19}$ The type I error was set at 0.05 corresponding to a confidence level of $95 \%$.

Statistical analysis was done using IBMC SPSS $\odot$ Statistics version 21 (IBM@ Corp., Armonk, NY, USA) and MedCalc $@$ version 12.5 (MedCalc $@$ Software bvba, Ostend, Belgium). The D'Agostino-Pearson test was performed to test the normality of numerical data distribution. Non-normally distributed numerical variables were presented as median and interquartile range and between group differences were compared using the Mann-Whitney U test. Qualitative variables were presented as number and percentage and differences between two groups were compared using the Pearson chi-square test. Receiver-operating characteristic (ROC) curve analysis was used to determine the value of $\mathrm{AMH}$ level for prediction of ovulation. Multivariable logistic regression was used to determine independent predictors of ovulation including AMH. Possible confounders that might affect the outcome of interest were adjusted for in the regression model to determine the independent effect of AMH. Kaplan-Meier analysis was used to examine the relation between the level of $\mathrm{AMH}$ and the time to ovulation. Separate curves were plotted for women with or without high AMH level and both curves were compared using the log-rank (Mantel-Cox) test. Hazard ratio for ovulation was estimated using the MantelHaenszel test. $\mathrm{P}<0.05$ was considered statistically significant.

\section{RESULTS}

A total of 100 women with PCOS participated in the study; their mean age was $25.55 \pm 3.54$ years (SD). 51 ranged from 20 to 25 years, 39 from 26 to 30 years and the remaining 10 ranged from 30 to 32 years. $39 \%$ of patients had optimal weight (BMI $20.1-25 \mathrm{~kg} / \mathrm{m}^{2}$ ), $48 \%$ of patients were overweight (BMI 25.1-30 kg/m²) and $13 \%$ of patients were obese (BMI $30.1-35 \mathrm{~kg} / \mathrm{m}^{2}$ ). $14 \%$ of patients were amenorrhoeic, $79 \%$ of patients had oligomenorrhea and $7 \%$ had cycles of normal frequency. 70 patients had primary infertility while the other 30 complained of secondary infertility. 45 had hirsutism with modified Ferriman-Gallwey score ranging from 9 to 
30 indicating androgen excess. The majority of patients (74) showed PCOS morphology on ultrasonography.

Successful ovulation was obtained in 72 women ranging between days 12 to 33 of the menstrual cycle with median of 21 , while 28 patients had undetectable ovulation till day 35. Comparison between ovulated and non-ovulated women in relation to patients' characteristics is shown in Tables 1 and 2. There was a strong correlation between most of the parameters of the hormonal profiles of patients and the incidence of ovulation (Table 3).

Table 1: Comparison between ovulated and non-ovulated women in relation to patients' characteristics.

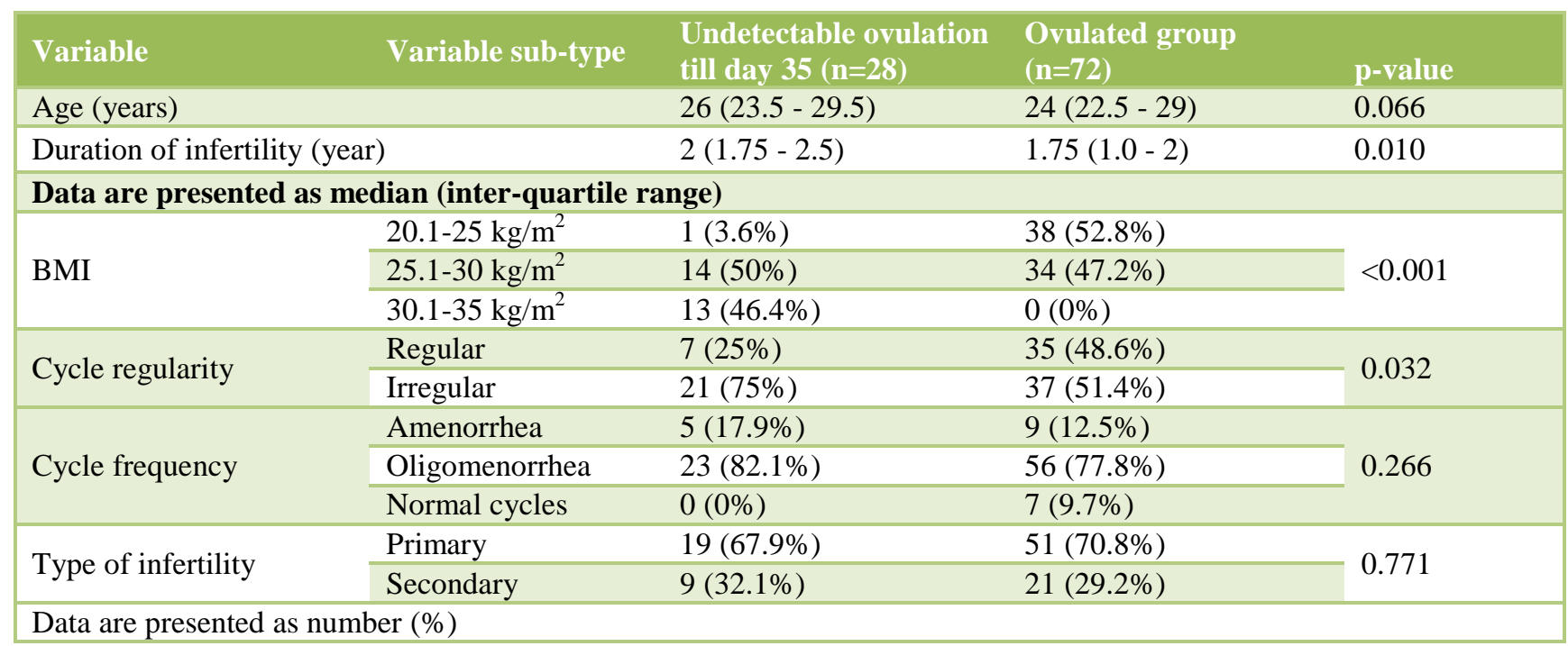

Table 2: Comparison between ovulated and nonovulated women in relation to hirsutism score and presence of PCOS morphology by U/S.

\begin{tabular}{|c|c|c|c|c|}
\hline Variable & $\begin{array}{l}\text { Variable } \\
\text { sub-type }\end{array}$ & $\begin{array}{l}\text { Undetec } \\
\text {-table } \\
\text { ovula- } \\
\text { tion till } \\
\text { day } 35 \\
(\mathrm{n}=28)\end{array}$ & $\begin{array}{l}\text { Ovulated } \\
\text { group } \\
(n=72)\end{array}$ & p-value \\
\hline \multirow{3}{*}{$\begin{array}{l}\text { Hirsutism } \\
\text { score }\end{array}$} & Score 0 & $\begin{array}{l}5 \\
(17.9 \%)\end{array}$ & $\begin{array}{l}35 \\
(48.6 \%)\end{array}$ & \multirow{3}{*}{$<0.001$} \\
\hline & $\begin{array}{l}\text { Score } \\
1-8\end{array}$ & $0(0.0 \%)$ & $\begin{array}{l}15 \\
(20.8 \%)\end{array}$ & \\
\hline & $\begin{array}{l}\text { Score } \\
9-30\end{array}$ & $\begin{array}{l}23 \\
(82.1 \%)\end{array}$ & $\begin{array}{l}22 \\
(30.6 \%)\end{array}$ & \\
\hline \multirow{2}{*}{$\begin{array}{l}\text { PCOS } \\
\text { morpholo } \\
\text { gy by } \\
\text { U/S }\end{array}$} & $\begin{array}{l}\text { No PCO } \\
\text { by U/S }\end{array}$ & $\begin{array}{l}11 \\
(39.3 \%)\end{array}$ & $\begin{array}{l}13 \\
(18.1 \%)\end{array}$ & \multirow{2}{*}{0.026} \\
\hline & $\begin{array}{l}\text { PCO by } \\
\text { U/S }\end{array}$ & $\begin{array}{l}17 \\
(60.7 \%)\end{array}$ & $\begin{array}{l}59 \\
(81.9 \%)\end{array}$ & \\
\hline
\end{tabular}

The median serum AMH level was significantly higher in women with failed ovulation $[4.05 \mathrm{ng} / \mathrm{mL}(3.7$ - 4.4)] than in ovulating women $[2.7 \mathrm{ng} / \mathrm{mL}(1.9-3.1)]$ ( $p<0.001)$. The best cutoff value of AMH for prediction of successful ovulation was $\leq 3.6 \mathrm{ng} / \mathrm{mL}$ (sensitivity = $97.2 \%$, specificity $=82.1 \%$ ) (Figure 1$)$. With a highly significant correlation between successful ovulation and AMH level $\leq 3.6 \mathrm{ng} / \mathrm{mL}$ (Figure 2). AMH level and hirsutism score were found to be highly significant determinants of successful ovulation ( $p<0.01$ and $p$ $<0.05$ respectively) (Table 4 ). Also, there was a highly significant correlation between AMH level and time to ovulation with shorter time from induction of ovulation till documented ovulation in women with $\mathrm{AMH} \leq 3.6$ $\mathrm{ng} / \mathrm{mL}(\mathrm{p}<0.0001)$ (Figure 3).

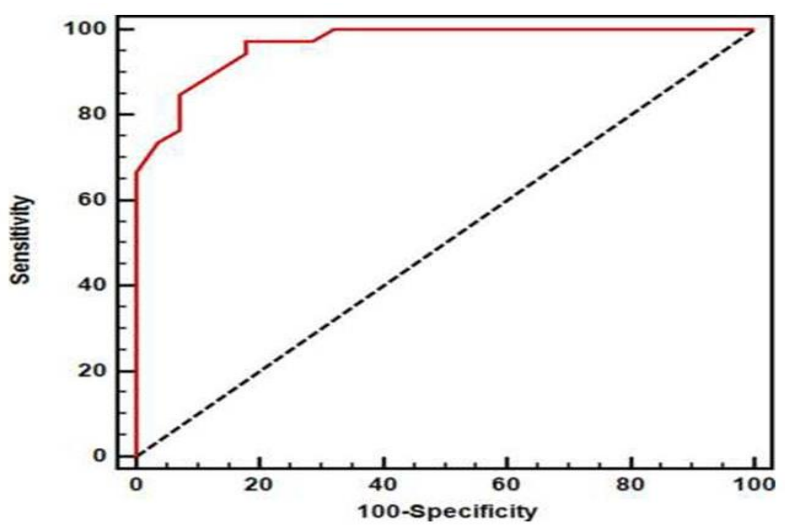

Figure 1: Receiver-operating characteristic (ROC) curve for the value of $\mathrm{AMH}$ level in prediction of successful ovulation. Area under the ROC curve = $0.97(95 \% \mathrm{CI}=0.91-0.99, \mathrm{P}<0.0001)$. 
Table 3: Comparison of the hormonal profile in ovulated women and those with undetectable ovulation till day 35.

\begin{tabular}{|llll|}
\hline Variable & Undetectable ovulation till day $35(\mathrm{n}=\mathbf{2 8})$ & Ovulated group $(\mathrm{n}=\mathbf{7 2})$ & $\mathrm{p}$-value \\
\hline Free testosterone $(\mathrm{ng} / \mathrm{dL})$ & $639.15(574.7-663.5)$ & $540.5(485.5-618.0)$ & 0.003 \\
\hline FSH $(\mathrm{mIU} / \mathrm{mL})$ & $6(5.0-7.7)$ & $7(6.0-8.15)$ & 0.031 \\
\hline LH $(\mathrm{mIU} / \mathrm{mL})$ & $9.5(8.0-14.0)$ & $8(6.0-9.4)$ & 0.001 \\
\hline LH/FSH Ratio & $1.67(1.23-2.30)$ & $1.16(0.89-1.42)$ & $<0.001$ \\
\hline TSH $(\mathrm{mIU} / \mathrm{mL})$ & $1.75(1.5-2.1)$ & $2(1.5-2.4)$ & 0.330 \\
\hline Prolactin $(\mathrm{ng} / \mathrm{mL})$ & $19(16.0-21.0)$ & $17(14.0-19.0)$ & 0.032 \\
\hline Data are presented as median (inter-quartile range) & & \\
\hline
\end{tabular}

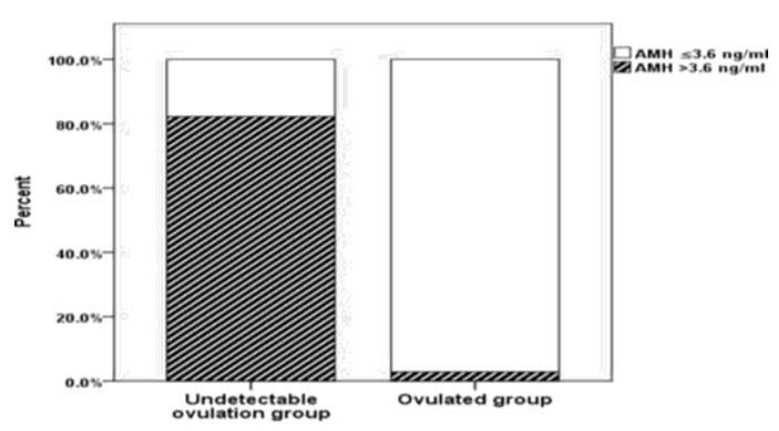

Figure 2: Percentage of women with AMH level >3.6 $\mathrm{ng} / \mathrm{mL}$ or $\leq 3.6 \mathrm{ng} / \mathrm{mL}$ among those who had successful ovulation and those who did not ovulate till day 35.

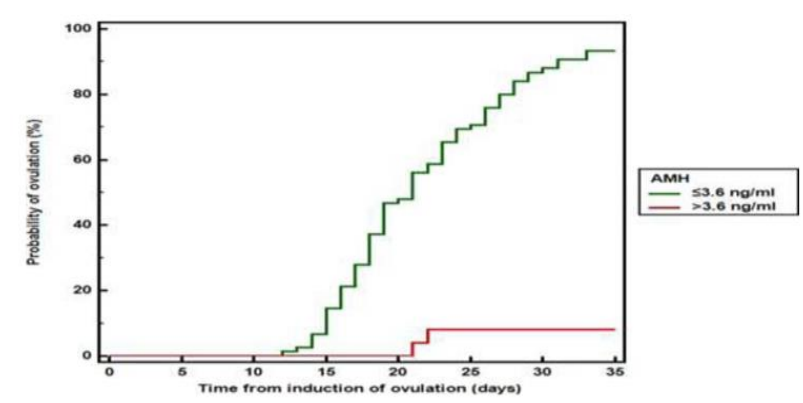

Figure 3: Kaplan-Meier curve for the time to ovulation in women with AMH level $\leq 3.6 \mathrm{ng} / \mathrm{mL}$ and those with AMH level $>3.6 \mathrm{ng} / \mathrm{mL}$. Hazard ratio = $6.12(95 \% \mathrm{CI}=3.69$ to $10.14, \mathrm{P}<0.0001)$.

Table 4: Multivariable logistic regression model for determinants of successful ovulation.

\begin{tabular}{|llllll|}
\hline Variable & B & SE & OR & $95 \%$ CI for OR & p-value \\
\hline AMH (ng/mL) & -6.55 & 2.34 & 0.00 & 0.00 to 0.14 & 0.005 \\
\hline Age (years) & -0.66 & 0.36 & 0.52 & 0.26 to 1.05 & 0.067 \\
\hline Secondary infertility* & 3.14 & 2.32 & 23.20 & 0.25 to 2194.26 & 0.176 \\
\hline Duration of infertility (years) & 0.79 & 1.29 & 2.2 & 0.17 to 27.83 & 0.542 \\
\hline Hirsutism score & -0.35 & 0.16 & 0.7 & 0.52 to 0.95 & 0.024 \\
\hline PCO changes by U/S $\dagger$ & -1.15 & 1.87 & 0.32 & 0.01 to 12.27 & 0.537 \\
\hline LH/FSH ratio & 1.00 & 1.51 & 2.73 & 0.14 to 52.57 & 0.506 \\
\hline Constant & 41.28 & & & & \\
\hline
\end{tabular}

$\mathrm{B}=$ regression coefficient; $\mathrm{SE}=$ standard error; $\mathrm{OR}=$ odds ratio; *Referenced to primary infertility; $\uparrow$ Referenced to no PCO changes by U/S.

\section{DISCUSSION}

In the current study, we found that baseline serum AMH levels to be negatively correlated with the response to ovulation induction with CC. We have identified a cutoff level of AMH $(3.6 \mathrm{ng} / \mathrm{mL})$, above which the chances of ovulation were significantly reduced $(97.2 \%$ of ovulated women had $\mathrm{AMH} \leq 3.6 \mathrm{ng} / \mathrm{mL}$ ). The influence of $\mathrm{AMH}$ levels on ovarian response to ovulation induction with $\mathrm{CC}$ in this study could reflect the correlation between serum AMH levels and severity of PCOS. Granulosa cells (GCs) of PCOS secrete much higher levels of AMH than those of normal ovaries, this suggests inhibition of ovulation and follicle maturation in PCOS. ${ }^{20}$

Women with PCOS could be divided into ovulatory and anovulatory depending on their GCs whether were low or high AMH producers. Ovulatory PCOS have significantly higher AMH production than normal women yet still anovulatory PCOS have GCs producing almost 18 times higher AMH than those of ovulatory PCOS. ${ }^{21}$ Thus, this rise of AMH in PCOS appears to be an intrinsic property of the GCs as confirmed by the presence of increased levels of AMH mRNA in these 
GCs, and this property even persists after stimulation for IVF. $^{22}$

These studies implies that the increased AMH levels are actually due to increased production of by each follicle rather than being secondary to increased follicle count. ${ }^{21}$ All this give rise to a very important question about the importance of decreasing this GCs AMH production in order to achieve successful ovulation in non-responder PCOS.

Other studies found AMH to be a useful marker for the prediction of ovarian response to ovulation induction in PCOS, one of them found almost the same cutoff value $(3.4 \mathrm{ng} / \mathrm{mL})$ to be a useful predictor of anovulation. ${ }^{23}$ Another study found serum AMH levels significantly higher in PCOS not responding to $\mathrm{CC}$, yet a much lower cutoff level was proposed $(1.2 \mathrm{ng} / \mathrm{mL})$ which could be attributed to the high BMI used where all patients were above $30 \mathrm{~kg} / \mathrm{m}^{2}$ unlike this study which included only $2 \%$ above this figure. ${ }^{24}$

Others reported conflicting results; one study found PCOS women with AMH levels $>7.7 \mathrm{ng} / \mathrm{mL}$ less likely to ovulate with $\mathrm{CC}$ induction, yet these values didn't reach significance. ${ }^{13}$ Others found AMH to be of limited value in the prediction of PCOS response to ovulation induction with CC. ${ }^{25,26}$ However, many other studies using other protocols for induction of ovulation in PCOS. ${ }^{12,20,27}$ have found $\mathrm{AMH}$ to be a very useful predictor of poor responder PCOS and even to be to be the most significant independent predictor for the FSH dosage needed to reach mono-follicular development for ovulation. Amer et al, found PCOS with high AMH levels to have a reduced chance to ovulate following laparoscopic ovarian diathermy (LOD). ${ }^{13}$ All this support the hypothesis of this study about the importance of $\mathrm{AMH}$ as a predictor of anovulation in women with PCOS in response to different modalities of treatment including ovulation induction with CC. Some studies even suggested AMH to be a possible predictor of pregnancy in IVF cycles done for women with PCOS, with the women producing relatively lower levels of AMH having the best outcome. ${ }^{28}$

These results drove the attention of many researchers to the possibility that the reduction of AMH levels in women with anovulatory PCOS might be essential in their treatment. Amer et al found AMH concentration significantly decreased following LOD and remained low at 3- and 6-month follow-up. ${ }^{13}$ Others found AMH levels to lower down following long-term treatment with metformin. ${ }^{29,30}$ Women treated with recombinant human FSH had lower serum AMH levels after treatment, also significant reduction of $\mathrm{AMH}$ protein in conditioned medium from GCs of women with PCOS after FSH treatment has been observed. ${ }^{31,32}$

\section{CONCLUSIONS}

The role of AMH in PCOS remains a key question that needs to be answered. Finding an anti-AMH therapy seems to be the upcoming quest in the management of anovulatory PCOS. Still the research in literature about the relation between AMH and PCOS is insufficient and invites further studies to find better solutions for the management of this disease.

Funding: No funding sources

Conflict of interest: None declared

Ethical approval: The study was approved by the Institutional Ethics Committee

\section{REFERENCES}

1. Battaglia C. The role of ultrasound and Doppler analysis in the diagnosis of polycystic ovary syndrome. Ultrasound Obstet Gynecol. 2003;22(3):225-32.

2. Seow KM, Lin YH, Hwang JL, Wang PH, Ho LT, Lin YH. Expression levels of haem oxygenase-1 in the omental adipose tissue and peripheral blood mononuclear cells of women with polycystic ovary syndrome. Hum Reprod. 2011;26(2):431-7.

3. Azziz R, Adashi EY. Stein and Leventhal: 80 years on. Am J Obstet Gynecol. 2015.

4. Froment P, Touraine P. Thiazolidinediones and Fertility in Polycystic Ovary Syndrome (PCOS). PPAR Res. 2006:73986.

5. La MA, Bertucci E, Giulini S, Tirelli A, Malavasi B, Volpe A. [Ovulation induction in anovulatory women]. Minerva Ginecol. 2006;58(6):489-97.

6. Revised 2003 consensus on diagnostic criteria and long-term health risks related to polycystic ovary syndrome. Fertil Steril. 2004;81(1):19-25.

7. Hughes E, Collins J, Vandekerckhove P. Ovulation induction with urinary follicle stimulating hormone versus human menopausal gonadotropin for clomiphene-resistant polycystic ovary syndrome. Cochrane Database Syst Rev. 2000;(2):CD000087.

8. Ghobadi C, Nguyen TH, Lennard MS, Amer S, Rostami-Hodjegan A, Ledger WL. Evaluation of an existing nomogram for predicting the response to clomiphene citrate. Fertil Steril. 2007;87(3):597-602.

9. Mitwally MF, Casper RF. Use of an aromatase inhibitor for induction of ovulation in patients with an inadequate response to clomiphene citrate. Fertil Steril. 2001;75(2):305-9.

10. Itman C, Mendis S, Barakat B, Loveland KL. All in the family: TGF-beta family action in testis development. Reproduction. 2006;132(2):233-46.

11. Pigny P, Jonard S, Robert Y, Dewailly D. Serum anti-Mullerian hormone as a surrogate for antral follicle count for definition of the polycystic ovary syndrome. J Clin Endocrinol Metab. 2006;91(3):9415.

12. El-Mazny A, Abou-Salem N. Anti-Mullerian hormone and antral follicle count for prediction of 
ovarian stimulation response in polycystic ovary syndrome. Gynecol Endocrinol. 2013;29(9):826-9.

13. Amer SA, Li TC, Ledger WL. The value of measuring anti-Mullerian hormone in women with anovulatory polycystic ovary syndrome undergoing laparoscopic ovarian diathermy. Hum Reprod. 2009;24(11):2760-6.

14. Aleyasin A, Aghahoseini M, Mokhtar S, Fallahi P. Anti-mullerian hormone as a predictive factor in assisted reproductive technique of polycystic ovary syndrome patients. Acta Med Iran. 2011;49(11):71520.

15. Azziz R, Carmina E, Dewailly D, DiamantiKandarakis E, Escobar-Morreale HF, Futterweit W. Positions statement: criteria for defining polycystic ovary syndrome as a predominantly hyperandrogenic syndrome: an Androgen Excess Society guideline. J Clin Endocrinol Metab. 2006;91(11):4237-45.

16. Azziz R, Woods KS, Reyna R, Key TJ, Knochenhauer ES, Yildiz BO. The prevalence and features of the polycystic ovary syndrome in an unselected population. J Clin Endocrinol Metab. 2004;89(6):2745-9.

17. Chao KC, Ho CH, Shyong WY, Huang CY, Tsai SC, Cheng HY. Anti-Mullerian hormone serum level as a predictive marker of ovarian function in Taiwanese women. J Chin Med Assoc. 2012;75(2):70-4.

18. Swets JA. Measuring the accuracy of diagnostic systems. Science. 1988;240(4857):1285-93.

19. Imani B, Eijkemans MJ, te Velde ER, Habbema JD, Fauser BC. Predictors of patients remaining anovulatory during clomiphene citrate induction of ovulation in normogonadotropic oligoamenorrheic infertility. J Clin Endocrinol Metab. 1998;83(7):2361-5.

20. Koninger A, Sauter L, Edimiris P, Kasimir-Bauer S, Kimmig R, Strowitzki T. Predictive markers for the FSH sensitivity of women with polycystic ovarian syndrome. Hum Reprod. 2014;29(3):518-24.

21. Pellatt L, Rice S, Mason HD. Anti-Mullerian hormone and polycystic ovary syndrome: a mountain too high? Reproduction. 2010;139(5):825-33.

22. Catteau-Jonard S, Jamin SP, Leclerc A, Gonzales J, Dewailly D, di CN. Anti-Mullerian hormone, its receptor, FSH receptor, and androgen receptor genes are overexpressed by granulosa cells from stimulated follicles in women with polycystic ovary syndrome. J Clin Endocrinol Metab. 2008;93(11):4456-61.

23. Mahran A, Abdelmeged A, El-Adawy AR, Eissa MK, Shaw RW, Amer SA. The predictive value of circulating anti-Mullerian hormone in women with polycystic ovarian syndrome receiving clomiphene citrate: a prospective observational study. J Clin Endocrinol Metab. 2013;98(10):4170-5.
24. El-Halawaty S, Rizk A, Kamal M, AboulHassan M, Al-Sawah H, Noah O. Clinical significance of serum concentration of anti-Mullerian hormone in obese women with polycystic ovary syndrome. Reprod BioMed Online. 2007;15(5):495-9.

25. Vaiarelli A, Drakopoulos P, Blockeel C, De VM, van d, V, Camus M. Limited ability of circulating antiMullerian hormone to predict dominant follicular recruitment in PCOS women treated with clomiphene citrate: a comparison of two different assays. Gynecol Endocrinol. 2015;1-4.

26. Kim JY, Yi G, Kim YR, Chung JY, Ahn JH, Uhm YK. Association between serum anti-Mullerian hormone level and ovarian response to mild stimulation in normoovulatory women and anovulatory women with polycystic ovary syndrome. Clin Exp Reprod Med. 2013;40(2):95-9.

27. Amer SA, Mahran A, Abdelmaged A, El-Adawy AR, Eissa MK, Shaw RW. The influence of circulating anti-Mullerian hormone on ovarian responsiveness to ovulation induction with gonadotrophins in women with polycystic ovarian syndrome: a pilot study. Reprod Biol Endocrinol. 2013;11:115.

28. Desforges-Bullet V, Gallo C, Lefebvre C, Pigny P, Dewailly D, Catteau-Jonard S. Increased antiMullerian hormone and decreased FSH levels in follicular fluid obtained in women with polycystic ovaries at the time of follicle puncture for in vitro fertilization. Fertil Steril. 2010;94(1):198-204.

29. Falbo A, Rocca M, Russo T, D'Ettore A, Tolino A, Zullo F. Serum and follicular anti-Mullerian hormone levels in women with polycystic ovary syndrome (PCOS) under metformin. J Ovarian Res. 2010;3:16.

30. Fleming R, Harborne L, MacLaughlin DT, Ling D, Norman J, Sattar N. Metformin reduces serum mullerian-inhibiting substance levels in women with polycystic ovary syndrome after protracted treatment. Fertil Steril. 2005;83(1):130-6.

31. La MA, Malmusi S, Giulini S, Tamaro LF, Orvieto R, Levratti P. Anti-Mullerian hormone plasma levels in spontaneous menstrual cycle and during treatment with FSH to induce ovulation. Hum Reprod. 2004;19(12):2738-41.

32. Pellatt L, Hanna L, Brincat M, Galea R, Brain H, Whitehead S. Granulosa cell production of antiMullerian hormone is increased in polycystic ovaries. J Clin Endocrinol Metab. 2007;92(1):240-5.

Cite this article as: Sweed MS, El-Kady OS, AbdElSalam A, Mostafa MM. Anti-Müllerian hormone and response to ovulation induction with clomiphene citrate in women with polycystic ovary syndrome. Int J Reprod Contracept Obstet Gynecol 2016;5:603-8 